Volume 10, Nomor 1, Mei 2018, pp 17-29 Copyright (C) 2017 Jurnal Akuntansi Maranatha, Program Studi Akuntansi, Fakultas Ekonomi, Universitas Kristen Maranatha. ISSN 2085-8698 | e-ISSN 2598-4977. http://journal.maranatha.edu

\title{
Pengaruh Dana Pihak Ketiga, Kredit Yang Disalurkan dan Kredit Non Lancar Terhadap Laba (The Impact Of Third parties funds, Distributed Loans On Profitabilites) (Studi Kasus Pada Bank Nusantara Parahyangan Cabang Sudirman)
}

\author{
Dwi Rianawati \\ Fakultas Ekonomi Program Sudi Magister Manajemen \\ Universitas Katolik Parahyangan \\ (Jln. Merdeka No. 30, Bandung) \\ dwirianawati@gmail.com \\ Nur Imam Taufik \\ Alumni Fakultas Ekonomi dan Bisnis - Universitas Padjadjaran Bandung \\ (Jalan Dipati Ukur No. 35 Bandung) \\ nurimamtaufik@gmail.com
}

\begin{abstract}
Bank as a financial institution is a business-oriented entity that is aiming to make profit/earnings through ethical ways including through fulfillment of customer needs and satisfaction. As commodities are processed and sold by the bank is fund that will also be the object of its business. Bank is a business entity which functions to collect funds from the public in the form of deposits, and also serves to distribute in the form of credit and other forms to the public or the debtor. The distribution is likely to impact the risk be less smooth return of the loan amount or also known as Non-Performing Loans (NPL), which will affect the company's financial banking. Non-performing loans are credit distributed loans, but the loans are substandard, doubtful and loss. The amount of data that is used as much as 42 months, they are the data of Third Party Fund, Distributed Loans and Non Performing Loans of Bank Nusantara Parahyangan, and also its profit from the period of January 2013- June 2016. The data were analyzed in this study using a linear regression model, and the results are Third Party Fund has significant effect on profit growth level at the Bank Nusantara Parahyangan Sudirman branch; The amount of Distributed Loans does not have significant effect on profit growth level at Bank Nusantara Parahyangan Sudirman branch; The amount of Non Performing Loans does not have significant effect on profit growth level at Bank Nusantara Parahyangan Sudirman branch; Research shows the variable of the Amount of Third Party Funds, Distributed Loans, and Non Performing Loans simultaneously have a significant effect on profit grow level at Bank Nusantara Parahyangan Sudirman branch.
\end{abstract}

Keywords: Impact of TPF, DL, NPL, Profit 


\section{Pendahuluan}

Kondisi dunia perbankan di Indonesia telah mengalami banyak perubahan dari waktu ke waktu. Perubahan ini disebabkan oleh faktor intenal dan eksternal. Perbankan memegang peranan penting dalam perekonomian suatu negara baik sebagai sumber permodalan maupun sebagai perantara keuangan dari dua pihak, yakni yang kelebihan dana dengan pihak yang kekurangan dana. Ekonomi masyarakat akan tumbuh dan berkembang sejalan dengan perkembangan dan kemajuan bank dalam menciptakan produk dan jasa-jasa keuangan untuk melayani kebutuhan masyarakat. Bank dituntut untuk dapat melihat dan memprediksi arah perekonomian dimasa depan sebagai acuan untuk dapat tumbuh dan berkembang dalam persaingan bisnis yang sehat, sekaligus sebagai penyandang dana keuangan bagi para pelaku bisnis, baik yang berskala lokal, nasional, maupun internasional.

Perbankan nasional pada tahun 1999 mulai menunjukkan perkembangan ke arah perbaikan meskipun masih mengalami tahapan-tahapan yang sulit dalam rangka konsolidasi dan menyeimbangkan posisi keuangan. Salah satu cara yang dapat digunakan untuk mengukur kinerja keuangan bank adalah dengan mengetahui laba karena salah satu tujuan utama pendirian sebuah perusahaan adalah untuk memperoleh laba. Bank sebagai lembaga keuangan merupakan suatu badan usaha yang berorientasi bisnis yaitu bertujuan untuk mendapatkan keuntungan/laba melalui cara-cara yang etis antara lain melalui pemenuhan kebutuhan dan kepuasan nasabah. Adapun komoditi yang diolah dan diperjualbelikan oleh bank adalah dana (fund) yang sekaligus juga menjadi objek usahanya. Bank merupakan badan usaha yang selain berfungsi menghimpun dana dari masyarakat dalam bentuk simpanan juga berfungsi menyalurkan dalam bentuk kredit dan bentuk-bentuk lainnya ke masyarakat atau debitur.

Dalam menghadapi persaingan yang semakin kompetitif, lembaga perbankan dituntut untuk mengejar orientasi bisnisnya dari profit oriented menjadi satisfaction oriented. Dengan memberikan layanan yang memuaskan kepada pelanggan akan banyak keuntungan yang diperoleh. Keuntungan yang tersebut antara lain, reaksi terhadap produsen berbiaya rendah, manfaat ekonomi retensi pelanggan versus perpetual prospecting, nilai kumulatif dari relasi berkelanjutan, daya persuasi worth of mouth, reduksi sensitivitas harga dan kepuasan pelanggan sebagai indikator kesuksesan bisnis di masa depan.

Laba perusahaan yang baik mencerminkan bahwa kinerja perusahaan yang baik karena laba merupakan ukuran kinerja dari suatu perusahaan, maka semakin tinggi laba yang dicapai perusahaan, mengindikasikan semakin baik kinerja perusahaan. Dengan demikian, apabila rasio keuangan perusahaan baik maka laba perusahaan juga baik.

\section{Kerangka Teoritis dan Hipotesis}

Bank berasal dari kata Italia Banco yang artinya banku. Banku inilah yang dipergunakan oleh banker untuk melayani kegiatan operasionalnya kepada para nasabah. Istilah bangku kemudian berganti secara resmi dan popular menjadi Bank. Bank termasuk perusahan industry jasa karena produknya hanya memberikan pelayanan jasa kepada masyarakat (hasibuan, 2002:1).

Sementara pengertian Bank menurut Undang-Undang Perbankan No.10 Tahun 1998 pasal 1 ayat 2 mengatakan bahwa : Bank adalah badan usaha yang menghimpun dana dari masyarakat dalam bentuk simpanan dan menyalurkannya kembali kepada masyarakat dalam bentuk kredit dan atau 
bentuk-bentuk lainnya dalam rangka meningkatkan taraf hidup rakyat banyak.

Sumber dana bank adalah usaha bank dalam memperoleh dana dalam rangka membiayai kegiatan operasinya. Adapun jenis-jenis sumber dana bank adalah:

1. Dana yang bersumber dari bank itu sendiri

Perolehan dana dari sumber bank itu sendiri adalah dana yang diperoleh dari dalam bank. Perolehan dana ini biasanya digunakan apabila bank mengalami kesulitan untuk memperoleh dana dari luar. Salah satu jenis dana yang bersumber dari bank itu sendiri adalah modal setor dari para pemegang sahamnya, Keuntungan sumber dana sendiri adalah tidak perlu membayar bunga yang relatif besar daripada jika meminjam ke lembaga lain, biaya yang timbul dari penerbitan saham adalah deviden yang diberikan kepada pemilik saham, namun masih lebih kecil bila dibandingkan dengan pinjaman dari lembaga keuangan lainnya.

Secara garis besar dapat disimpulkan pencarian dana yang bersumber bank itu sendiri terdiri dari:

a. Setoran modal dari pemegam saham, merupakan dari modal dari para pemegang saham lama atau pemegang saham baru

b. Cadangan lama, merupakan yang setiap tahun dicadangkan oleh bank dan sementara waktu belum digunakan

c. Laba bank yang belum di bagi, merupakan laba tahun berjalan tapi belum dibagikan kepada para pemegang saham

2. Dana yang berasal dari masyarakat luas

Sumber dana ini merupakan sumber dana terpenting bagi kegiatan operasi suatu bank dan ukuran keberhasilan bank jika mampu membiayai operasinya dari sumber ini. Pentingnya sumber dana dari masyarakat luas, disebabkan sumber dana ini yang paling utama. Sumber dana yang juga disebut sumber dana pihak ketiga, disamping mudah untuk mencarinya juga tersedia di masyarakat dan persyaratan untuk mencarinya juga tidak sulit.

3. Dana yang bersumber dari lembaga lainnya

Sumber dana ini merupakan sumber dana tambahan jika bank mengalami kesulitan dalam pencairan sumber dana dari modal sendiri dan sumber dana dari pihak masyarakat. Pencarian sumber dana ini relative mahal dan sifatnya hanya sementara waktu saja. Perolehan dana antara lain dapat diperoleh dari

a. Pinjaman antar bank

b. Pinjaman dari bank-bank luar negeri

c. Surat Berharga Pasar Uang (SBPU)

Dalam hal ini pihak perbankkan menerbitkan SBPU kemudian diperjualbelikan kepada pihak yang berminat, baik perusahaan keuangan maupun nonkeuangan.

Bank mempunyai empat alternatif untuk menghimpun dana untuk kepentingan usahanya, yaitu dana sendiri (dana pihak kesatu), dana pinjaman (dana pihak kedua), dana dari deposan (dana pihak ketiga), dan sumber dana lain. Menurut Kasmir dalam (2012:64) dana pihak ketiga adalah dana yang berasal dari masyarakat luas yang merupakan sumber dana terpenting bagi kegiatan operasional suatu bank dan merupakan ukuran keberhasilan Sumber dana ini merupakan sumber dana terpenting bagi kegiatan operasi suatu bank dan merupakan ukuran keberhasilan bank. jika mampu membiayai operasinya dari sumber dana ini. Pencairan dari sumber ini relatif 
paling mudah jika dibandingkan dengan sumber lainnya. Dana pihak ketiga merupakan sumber likuiditas untuk memperlancar pembiayaan yang terdapat di sisi aktiva neraca bank.

Dalam pengertian sederhana kredit merupakan penyaluran dana dari pihak pemilik dana kepada pihak yang memerlukan dana. Penyaluran dana tersebut didasarkan kepada kepercayaan yang diberikan oleh pemilik dana kepada penggunan dana. Dalam baahasa latin, kredit berasal dari kata "credere" yang artinya percaya. Artinya pihak yang memberikan kredit percaya kepada pihak yang menerima kredit, bahwa kredit yang diberikan akan terbayar. Dilain pihak, penerima kredit mendapat kepercayaan dari pihak yang memberikan pinjaman, sehingga pihak peminjam berkewajiban untuk mengembalikan kredit yang telah diterimanya. Beberapa ahli menerjemahkan kredit sebagai berikut :

a) Kredit itu adalah suatu pemberian prestasi yang balas prestasinya (kontra prestasi) akan terjadi pada suatu waktu dihari yang akan dating (Hasibuan 2008:75).

b) Dalam undang-undang perbankan No. 1 Tahun 1998, kredit adalah penyedia uang atau tagihan yang dapat dipersamakan dengan itu, berdasarkan persetujuan atau kesepakatan pinjam meminjam antara bank dan pihak lain yang mewajibkan pihak peminjam untuk melunasi utangnya setelah jangka waktu tertentu dengan pemberian bunga.

Pada dasarnya fungsi kredit merupakan pelayanan kepada masyarakat dalam memenuhi kebutuhannya untuk meningkatkan usahanya. Masyarakat disini merupakan individu, pengusaha, lembaga, dan badan usaha yang membutuhkan dana. KRedit bergungsi membantu masyarakat dalam memenuhi kebutuhannya melalui penyaluran dana yang diberikan oleh bank (ismail, 2011:96).

Kredit tidak lancar adalah kredit yang masih dilakukan pembayarannya, tetapi lebih lambat dari jadwal yang seharusnya. Kredit tidak lancar dapat dikelompokkan menjadi tiga, yaitu kredit kurang lancar, kredit diragukan, kredit macet. Secara garis besar klasifikasi kredit kredit tidak lancar menurut Fahmi (2011:73) adalah sebagai berikut :

1. Kredit kurang lancar, usaha kredit non KPR ada tunggakan angsuran pokok yang lebih lama dari seharusnya. Misalnya untuk kredit yang masa angsurannya bulanan terdapat tunggakan satu bulan tetapi belum sampai dua bulan. Sedangkan kredit yang anggsurannya 6 bulanan terdapat tunggakan, namun belum melampaui 12 bulan. Bagi kredit BPR, ada tunggakan angsuran pokok yang melebihi 6 bulanan, tetapi belum melebihi 9 bulan.

2. Kredit yang diragukan, adalah kredit yang tidak termasuk kurang lancar, tetapi kredit yersebut dapat diselamatkan dan agunanya $\geq 75 \%$ utang debitur, atau kredit yang tidak dapat diselamatkan tetapi agunannya masih $\geq 100 \%$ utang debitur.

3. Kredit macet, adalah kredit yang sejak \pm 21 bulan dikategorikan diragukan, belum ada pelunasan atau penyelamatan kredit. Kredit tersebut penyelesaiannya telah diserahkan ke Pengadilan Negeri atau Badan Usaha Piutang Negara (BUPN) atau telah diajukan penggantian rugi kepada perusahaan asuransi kredit

Laba yang peroleh tidak dapat dipastikan, oleh karena itu dibutuhkan suatu prediksi pertumbuhan laba. Pertumbuhan laba adalah perubahan persentase kenaikan laba yang diperoleh perusahaan. Pertumbuhan laba yang baik mengisyaratkan bahwa perusahaan mempunyai kinerja yang baik, yang pada akhirnya akan meningkatkan nilai perusahaan. Dividen yang akan dibayar 
di masa mendatang besarannya sangat bergantung pada prospek pertumbuhan laba dan pertumbuhan perusahaan itu sendiri, semakin tinggi laba perusahaan, maka semikin besar jumlah dividen yang akan dibayarkan.

\section{Hipotesis}

Hipotesis merupakan dugaan sementara yang masih belum teruji kebenarannya dan masih harus dibuktikan secara empiris berdasarkan fakta-fakta yang ada. Hipotesis akan ditolak jika memang salah atau diterima jika fakta-fakta membenarkan. Berdasarkan pokok-pokok permasalahan yang telah dikemukakan diatas maka dapat dirumuskan hipotesis yang merupakan kesimpulan sementara terhadap permasalahan dalam penelitian ini sebagai berikut:

H1 : Terdapat pengaruh Dana Pihak Ketiga (DPK) terhadap laba pada Bank Nusantara Parahyangan Cabang Sudirman .

H2 : Terdapat pengaruh kredit yang disalurkan berpengaruh terhadap laba pada Bank Nusantara Parahyangan Cabang Sudirman.

H3 : Terdapat pengaruh kredit non lancar terhadap laba pada Bank Nusantara Parahyangan Cabang Sudirman .

H4 : Terdapat pengaruh Dana Pihak Ketiga, Kredit dan kredit non lancar secara simultan terhadap laba pada Bank Nusantara Parahyangan Cabang Sudirman .

\section{Metode Penelitian}

Menurut Sugiono menyatakan bahwa, definisi objek penelitian adalah sebagai berikut : "Objek penelitian merupakan suatu atribut atau sifat atau nilai dari orang, objek atau kegiatan yang mempunyai variasi tertentu yang ditetapkan oleh peneliti untuk dipelajari dan kemudian ditarik kesimpulannya". Objek penelitian disini adalah Bank Nusantara Parahyangan Cabang Sudirman Periode penelitian yang akan dipergunakan dalam analisis tersebut adalah data Laporan bulan Januari 2014 Sampai dengan Bulan Juni. 2016

Di dalam melakukan penelitian ini, jenis metode yang digunakan adalah deskriptif dan verifikatif. Penelitian deskriptif digunakan untuk memberikan penjelasan mengenai perkembangan DPK, KYD, NPL dan Laba. Sedangkan verifikatif digunakan untuk menguji pengaruh DPK, KYD, NPL terhadap laba. Metode deskriptif ini adalah untuk membuat deskripsi, gambaran atau lukisan secara sistematis, faktual dan akurat mengenal fakta-fakta serta hubungan antar fenomena yang diselidiki. Sedangkan penelitian verifikatif merupakan suatu metode dimana pendekatannya dapat berupa exploratory method atau experimental dengan kerangka berpikir deductiveinductive thinking. Dimana menurut Jogiyanto dalam buku berjudul "Metodologi Penelitian Bisnis" (2010:35) mengatakan bahwa metode deduktif merupakan pendekatan saintifik menggunakan struktur teori untuk membentuk hipotesis dan kemudian menggunakan fakta atau data empiris untuk menguji hipotesis untuk mendapatkan kesimpulan. Sedangkan pendekatan naturalis menggunakan data untuk mengambil kesimpulan tanpa menggunakan hipotesis. Dan jika hipotesis diperlukan dibentuk dari data yang diobservasi dan dikumpulkan terlebih dahulu, pembentukannya berdasarkan data yang ada

\section{Hasil Penelitian dan Pembahasan}

Teknik analisis deskriptif bertujuan untuk menjelaskan mengenai keseluruhan data yang dikumpulkan dengan memaparkan, 
mengelompokkan, dan mengklasifikasikan ke dalam tabel yang kemudian diberi penjelasan satu persatu. Variabel yang digunakan dalam penelitian ini adalah laba, dana pihak ketiga, kredit yang disalurkan dan Non Performing Loan (NPL).

Tabel 1

\section{Data Laba Periode Januari 2013-Juni 2016}

\begin{tabular}{|l|r|r|r|r}
\hline \multirow{2}{*}{\multicolumn{1}{c|}{ Bulan }} & \multicolumn{4}{|c}{ Laba (y) (Rp) } \\
\cline { 2 - 6 } & \multicolumn{1}{|c|}{$\mathbf{2 0 1 3}$} & \multicolumn{1}{c}{$\mathbf{2 0 1 4}$} & \multicolumn{1}{c}{$\mathbf{2 0 1 5}$} & \\
\hline Januari & $768,123,456.86$ & $6.588 .113 .143,06$ & $9,335,414,313.13$ & 11 \\
\hline Februari & $10,986,802,706.08$ & $12.987 .802 .707,97$ & $19,073,688,241.29$ & 2 \\
\hline Maret & $20,513,818,982.00$ & $22,518,808,480.00$ & $33,058,986,135.23$ & 3 \\
\hline April & $38,794,906,882.87$ & $43,282,907,484.79$ & $37,017,662,266.30$ & 4 \\
\hline Mei & $62,019,245,766.50$ & $59,196,393,845.04$ & $35,264,401,442.28$ & 5 \\
\hline Juni & $45,898,745,631.00$ & $44,289,207,201.37$ & $57,859,138,649.50$ & 6 \\
\hline Juli & $58,187,654,289.58$ & $63,253,707,556.76$ & $74,023,477,597.31$ & \\
\hline Agustus & $65,989,685,212.44$ & $72,989,675,124.43$ & $84,922,428,486.89$ & \\
\hline September & $89,452,110,960.45$ & $87,434,630,904.52$ & $89,412,598,744.78$ & \\
\hline October & $50,898,221,635.23$ & $87,434,630,904.52$ & $87,434,630,904.52$ & \\
\hline November & $45,963,458,611.58$ & $91,241,385,289.18$ & $112,067,623,625.45$ & \\
\hline Desember & $98,769,548,581.21$ & $100,357,678,348.09$ & $100,357,678,348.09$ & \\
\hline Nilai Maksimum & $\mathbf{9 8 , 7 6 9 , 5 4 8 , 5 8 1 . 2 1}$ & $\mathbf{1 0 0 , 3 5 7 , 6 7 8 , 3 4 8 . 0 9}$ & $\mathbf{1 1 2 , 0 6 7 , 6 2 3 , 6 2 5 . 4 5}$ & $\mathbf{6}$ \\
\hline Nilai Minimum & $\mathbf{7 6 8 , 1 2 3 , 4 5 6 . 8 6}$ & $\mathbf{6 , 5 8 8 , 1 1 3 , 1 4 3 . 0 6}$ & $\mathbf{9 , 3 3 5 , 4 1 4 , 3 1 3 . 1 3}$ & $\mathbf{1 1}$ \\
\hline Rata-rata & $\mathbf{4 9 , 0 2 0 , 1 9 3 , 5 5 9 . 6 5}$ & $\mathbf{5 5 , 9 9 9 , 9 1 8 , 7 6 1 . 5 6}$ & $\mathbf{6 1 , 6 5 2 , 3 1 0 , 7 2 9 . 5 6}$ & $\mathbf{4}$ \\
\hline
\end{tabular}

Penghimpunan dana di Bank BNP bersumber pada 2 (dua) sumber antara lain yang berasal dari masyarakat penyimpan (Pihak Ketiga) dan yang berasal dari Institusi perbankan (penempatan bank lain). Upaya untuk mempertahankan Dana pihak ketiga oleh Bank dilakukan dengan cara menjual beberapa produk Simpanan seperti Giro, Tabungan dan Deposito Berjangka, di mana masing-masing produk memiliki turunannya sendiri-sendiri yaitu fitur tiap-tiap turunan produk simpanan disesuaikan dengan target market yang dibidik. Di samping melakukan direct sale atas produk-produk simpanan yang ada,

diketahui nilai maksimum, nilai minimum dan rata-rata laba dari Januari 2014 sampai dengan Juni 2016. Pada tahun 2014 (Januari - Desember) laba memiliki nilai maksimum sebesar 100.357.678.348,09, nilai minimum sebesar 6.588.113.143,06 dan rata-rata sebesar 55.999,918,761.56. Pada tahun
2015 (Januari - Desember) laba memiliki nilai maksimum sebesar 112.067.623.625,45, nilai minimum sebesar 9.335.414.313,13 dan rata-rata sebesar 61.652.310.729,56 dan pada tahun 2016 (Januari - Juni) laba memiliki nilai maksimum sebesar 67.350.454.960,10, nilai minimum sebesar 10.722.851.632,45 dan rata-rata sebesar 40.645.921.470,17.

Bank BNP juga mengadakan beberapa program-program reguler untuk menarik dana dari masyarakat melalui kegiatan-kegiatan promosi lainnya.

\section{Tabel 2}

\section{Data Dana Pihak Ketiga (DPK) Periode Januari 2013-Juni 2016}

\begin{tabular}{|c|c|c|c|c|}
\hline \multirow{2}{*}{ Bulan } & \multicolumn{4}{|c|}{ Dana Pihak Ketiga (DPK) (x1) (Rp) } \\
\hline & 2013 & 2014 & 2015 & 2016 \\
\hline Januari & $169,287,598,874,00$ & $158,999,333,000.00$ & $993,473,910,337,19$ & $826,880,160,973.53$ \\
\hline Februari & $700,487,596,509.00$ & $862,487,395,922.00$ & \begin{tabular}{l|l|}
$952,309,015,120.98$ \\
\end{tabular} & $843,002,015,664.62$ \\
\hline Maret & $1,080,009,875,463.00$ & $1,189,797,509,285.65$ & $962,153,865,005.00$ & $847,462,601,075.20$ \\
\hline April & $1,165,258,974,561.00$ & $\begin{array}{ll}1,208,602,641,228.82 \\
\end{array}$ & 918,719,799,855.71 & $909,878,843,243.97$ \\
\hline Mei & $904,875,985,126.00$ & $1,222,502,386,248.94$ & $904,478,457,873.07$ & $905,628,161,453.70$ \\
\hline Juni & $1,088,741,598,772.00$ & $1,207,181,303,284.78$ & $935,912,928,842.88$ & $940,839,658,236.3$ \\
\hline Juli & $1,070,008,975,462.00$ & \begin{tabular}{l|l}
$1,195,101,112,113.98$ \\
\end{tabular} & $919,620,037,877.06$ & \\
\hline \begin{tabular}{|l|} 
Agustus \\
\end{tabular} & \begin{tabular}{|l|}
$1,201,621,581,124.00$ \\
\end{tabular} & \begin{tabular}{l|l}
$1,174,002,638,641.75$ \\
\end{tabular} & $\begin{array}{l}945,984,015,414.08 \\
\end{array}$ & \\
\hline September & $1,247,566,877,418.00$ & \begin{tabular}{l|l}
$1,151,756,345,558.09$ \\
\end{tabular} & $916,028,813,948.20$ & \\
\hline \begin{tabular}{|l|} 
October \\
\end{tabular} & $980,444,558,260.00$ & $1,100,635,970,127.84$ & $\begin{array}{l}879,526,707,936.67 \\
\end{array}$ & \\
\hline November & \begin{tabular}{|l|}
$1,052,884,886,962.00$ \\
\end{tabular} & \begin{tabular}{l|l|}
$1,053,884,881,963.96$ \\
\end{tabular} & $874,519,062,938.43$ & \\
\hline Desember & \begin{tabular}{|l|}
$1,058,068,824,482,00$ \\
\end{tabular} & \begin{tabular}{l|l|}
$1,057,068,959,937.01$ \\
\end{tabular} & $879,249,449,025.74$ & \\
\hline Nilai Maksimum & $1,247,566,877,418.00$ & $1,222,502,386,248.94$ & \begin{tabular}{|l|l|}
$993,473,910,337.19$ \\
\end{tabular} & $940,839,658,236.34$ \\
\hline \begin{tabular}{|l|} 
Nilai Minimum \\
\end{tabular} & $169,287,598,874.00$ & $158,999,333,000.00$ & \begin{tabular}{|l|l|}
$874,519,062,938.43$ \\
\end{tabular} & $826,880,160,973$ \\
\hline Rata-rata & $976,604,777,751.08$ & 1,048,501,706,442.73 & $923,498,005,347.92$ & $878,948,573,441.2$ \\
\hline
\end{tabular}

Dari tabel 2 diatas, dapat diketahui nilai minimum dan rata-rata dana pihak ketiga dari Januari 2014 sampai dengan Juni 2016. Pada tahun 2014 (Januari Desember) dana pihak ketiga memiliki nilai maksimum sebesar 1.222.502.386.248,94, nilai minimum sebesar 158.999.333.000,00 dan rata-rata sebesar 1.048.501.706.442,73. Pada tahun 2015 (Januari - Desember) dana pihak ketiga memiliki nilai maksimum sebesar 993.473.910.337,19, nilai minimum sebesar 874.519.062.938,43 dan rata-rata sebesar 923.498.005.347,92 dan pada tahun 2016 (Januari - Juni) dana pihak ketiga memiliki nilai maksimum sebesar 940.839.658.236,34, nilai minimum sebesar 826.880.160.973,53 dan rata-rata sebesar 878.948.573.441,23. 
Target pembiayaan Bank BNP dalam menyalurkan kredit adalah bisnis ritel, commercial dan consumer loan. Ditengah melambatnya pertumbuhan perekonomian nasional, Manajemen memilih untuk menunda penyaluran kredit konsumer karena masih memiliki tingkat risiko relatif lebih tinggi dibandingkan penyaluran kredit untuk sektor produktif seperti modal kerja dan lainnya. Penyediaan dana/pembiayaan terhadap Bisnis Komersil meliputi hampir semua lini bisnis yang ada yang mempunyai tujuan komersil dan produktif, namun secara spesifik dibatasi menurut segmen bisnisnya, di mana segmen Menengah ke Bawah menjadi fokus pembiayaan dari bisnis komersil Bank BNP saat ini. Melalui penjualan jenis produk pinjaman Bank BNP seperti Kredit Modal Kerja yang menggunakan fasilitas Pinjaman Rekening Koran (PRK) dan Pinjaman Investasi dengan skim Time Loan-nya yang dapat direvolving bahkan digunakan sebagai pembiayaan untuk transaksi ekspor dan impor. Kredit Tanpa Agunan (BNP KTA) merupakan salah satu jenis pinjaman yang ditawarkan Bank BNP, produk yang bersifat unsecured ini cukup memberikan kontribusi terhadap pencapaian portofolio pinjaman dan menyumbang spread margin yang cukup baik. Mengingat return on payment KTA ini memiliki risiko yang cukup tinggi dan tidak adanya jaminan/agunan yang menjadi back up atas pinjaman tersebut, maka mitigasi terhadap inherent risk yang ada pada pinjaman ini juga cukup ketat, guna menghindari adanya risiko gagal bayar di kemudian hari sehingga margin pendapatannya diharapkan dapat memberikan kontribusi yang baik bagi pencapaian Net Interest Margin (NIM). Orientasi bisnis pembiayaan konsumtif di Bank BNP adalah menyalurkan pinjaman kepada penggunaan yang sifatnya komsumtif non produktif, berupa kredit pada pemilikan rumah, kredit pembelian mobil dan kredit konsumtif lainnya yang tidak ditujukan untuk usaha produktif. Klasifikasi pinjaman Konsumen di sini termasuk di dalamnya adalah kredit yang diberikan kepada karyawan. Produkproduk Pembiayaan Konsumtif yang dijual antara lain:

1. KPR BNP/Housing Loan, adalah pemberian fasilitas kredit untuk pembelian/kepemilikan rumah / ruko / rukan / kavling/ konstruksi / renovasi atau fasilitas take over dengan tujuan pemakaian pribadi/konsumsi maupun investasi.

2. KMG BNP/Kredit Multi Guna/Multipurpose Loan, adalah pemberian fasilitas pinjaman dengan tujuan multi guna yang agunannya dapat berupa sertifikat Rumah/Ruko/Rukan yang nilainya marketable.

3. KPM BNP/Vehicle Loan adalah pembiayaan fasilitas kredit untuk pembelian/kepemilikan kendaraan bermotor baru beroda empat untuk keperluan pribadi.

4. Kredit Tanpa Agunan, adalah merupakan jenis kredit dengan tujuan konsumtif yang penggunaannya dapat ditujukan untuk Segmen Mikro yang selama ini telah berjalan, Bank BNP merencanakan dan melakukan upaya untuk transformasi produk maupun segmen dari Mikro ke Lower SME (Rp250 juta-Rp500 juta) yang bertujuan meningkatkan produktivitas sambil mengontrol tingkat risiko yang dapat diterima. Perubahan cara kerja dan Standard Operating Procedure (SOP) yang telah disesuaikan juga akan diterapkan pada tahun 2016 yang diharapkan ke depannya akan membuat kualitas lower SME yang baik dan growth yang sustainable. 
Tabel 3

\section{Data Kredit Yang Disalurkan (KYD) Periode Januari 2013-Juni 2016}

\begin{tabular}{|c|c|c|c|c|}
\hline \multirow{2}{*}{ Bulan } & \multicolumn{4}{|c|}{ Kredit Yang Disalurkan (KYD) (x2) (Rp) } \\
\hline & 2013 & 2014 & 2015 & 2016 \\
\hline \begin{tabular}{|l|} 
Januari \\
\end{tabular} & $524,452,145,206$ & $\begin{array}{l}565,434,898,781 \\
\end{array}$ & $534,669,321,441$ & $481,641,506,257$ \\
\hline Februari & $550,458,921,060$ & $590,452,930,395$ & $516,930,442,680$ & $478,468,363,489$ \\
\hline Maret & $456,875,495,120$ & $483,200,517,888$ & $510,898,769,534$ & $501,647,304,534$ \\
\hline April & $424,458,961,226$ & $585,838,325,068$ & $523,371,889,624$ & $462,644,309,992$ \\
\hline Mei & $\begin{array}{l}602,001,455,756 \\
\end{array}$ & $589,724,546,910$ & $527,457,011,118$ & $4558,660,738,32$ \\
\hline Juni & $428,621,695,242$ & $486,647,124,417$ & $529,428,221,096$ & $461,265,212,51$ \\
\hline Juli & $520,041,256,174$ & $598,041,943,900$ & $528,125,408,992$ & \\
\hline \begin{tabular}{|l|} 
Agustus \\
\end{tabular} & $501,687,498,516$ & $560,128,561,930$ & $529,026,847,192$ & \\
\hline September & $520,821,469,874$ & $542,905,609,011$ & $529,544,040,547$ & \\
\hline \begin{tabular}{|l|} 
October \\
\end{tabular} & $542,587,455,412$ & $540,770,985,624$ & $517,429,018,710$ & \\
\hline November & $490,862,286,421$ & $528,776,632,889$ & $499,146,769,505$ & \\
\hline Desember & $586,242,001,480$ & $526,226,109,989$ & $487,603,908,595$ & \\
\hline \begin{tabular}{|l|l} 
Nilai Maksimum \\
\end{tabular} & $602,001,455,756$ & $598,041,943,900$ & $534,669,321,441$ & $501,647,304,534$ \\
\hline \begin{tabular}{|l|} 
Nilai Minimum \\
\end{tabular} & $424,458,961,226$ & $483,200,517,888$ & $487,603,908,595$ & $458,660,738,3$ \\
\hline \begin{tabular}{|l|} 
Rata-rata \\
\end{tabular} & $512,425,886,791$ & $549,845,682,234$ & $519,469,304,086$ & $474,054,572,5$ \\
\hline
\end{tabular}

Tabel 4

Data Non Performing Loan (NPL) Periode Januari 2004-Juni 2016

\begin{tabular}{|l|c|c|c|c|}
\hline \multirow{2}{*}{\multicolumn{1}{|c|}{ Bulan }} & \multicolumn{4}{|c|}{ Non Performing Loan (NPL) (X3) } \\
\cline { 2 - 5 } & 2013 & $\mathbf{2 0 1 4}$ & $\mathbf{2 0 1 5}$ & \multicolumn{1}{c|}{2016} \\
\hline Januari & $0.21 \%$ & $0.22 \%$ & $0.67 \%$ & $0.38 \%$ \\
\hline Februari & $0.18 \%$ & $0.19 \%$ & $0.52 \%$ & $0.22 \%$ \\
\hline Maret & $0.19 \%$ & $0.19 \%$ & $0.54 \%$ & $0.19 \%$ \\
\hline April & $0.10 \%$ & $0.10 \%$ & $0.53 \%$ & $0.19 \%$ \\
\hline Mei & $0.19 \%$ & $0.17 \%$ & $0.39 \%$ & $1.13 \%$ \\
\hline Juni & $0.20 \%$ & $0.16 \%$ & $0.23 \%$ & $1.13 \%$ \\
\hline Juli & $0.22 \%$ & $0.16 \%$ & $0.30 \%$ & \\
\hline Agustus & $0.19 \%$ & $0.20 \%$ & $0.29 \%$ & \\
\hline September & $0.04 \%$ & $0.01 \%$ & $0.30 \%$ & \\
\hline October & $0.19 \%$ & $0.24 \%$ & $0.35 \%$ & \\
\hline November & $0.20 \%$ & $0.23 \%$ & $0.35 \%$ & \\
\hline Desember & $0.18 \%$ & $0.24 \%$ & $0.53 \%$ & \\
\hline Nilai Maksimum & $\mathbf{0 . 2 2} \%$ & $\mathbf{0 . 2 4} \%$ & $\mathbf{0 . 6 7} \%$ & $\mathbf{1 . 1 3} \%$ \\
\hline Nilai Minimum & $\mathbf{0 . 0 4} \%$ & $\mathbf{0 . 0 1} \%$ & $\mathbf{0 . 2 3} \%$ & $\mathbf{0 . 1 9} \%$ \\
\hline Rata-rata & $\mathbf{0 . 1 7} \%$ & $\mathbf{0 . 1 8} \%$ & $\mathbf{0 . 4 2} \%$ & $\mathbf{0 . 5 4} \%$ \\
\hline
\end{tabular}

Dari tabel 4. diatas, dapat diketahui nilai maksimum, nilai minimum dan rata-rata Non Performing Loan dari Januari 2014 sampai dengan Juni 2016. Pada tahun 2014 (Januari - Desember) Non Performing Loan memiliki nilai maksimum sebesar $0,24 \%$, nilai minimum sebesar $0,01 \%$ dan rata-rata sebesar 0,18\%. Pada tahun 2015 (Januari Desember) Non Performing Loan memiliki nilai maksimum sebesar $0,67 \%$, nilai minimum sebesar $0,23 \%$ dan rata-rata sebesar $0,42 \%$ dan pada tahun 2016 (Januari - Juni) Non Performing Loan memiliki nilai maksimum sebesar $1,13 \%$, nilai minimum sebesar $0,19 \%$ dan rata-rata sebesar $0,54 \%$.

\section{Uji Asumsi Klasik}

Sebelum dilakukan perhitungan regresi linear berganda, terlebih dahulu dilakukan uji normalitas, heterokedastisitas, autokorelasi dan multikolinieritas, dengan hasil sebagai berikut

\section{Pengujian Normalitas Data}

Berdasarkan hasil regresi pada lampiran, ditemukan bahwa besarnya Jarque-Bera Normality test statistic adalah 2.704857 . Kemudian dibandingkan dengan $\chi^{2}$ tabel $(0,05)$ dengan degree of freedom adalah $3=$ 7.815. Berdasarkan hal tersebut, maka dapat dijelaskan bahwa model empiris yang digunakan mempunyai residual atau faktor pengganggu yang berdistribusi normal, karena Jarque-Bera Normality test statistic $<$ degree of freedom atau membandingkan nilai probability dengan $\alpha=5 \%$ yaitu 0.259 $>0.05$ (berdistribusi normal). Berikut diagram hasil uji normalitas data.

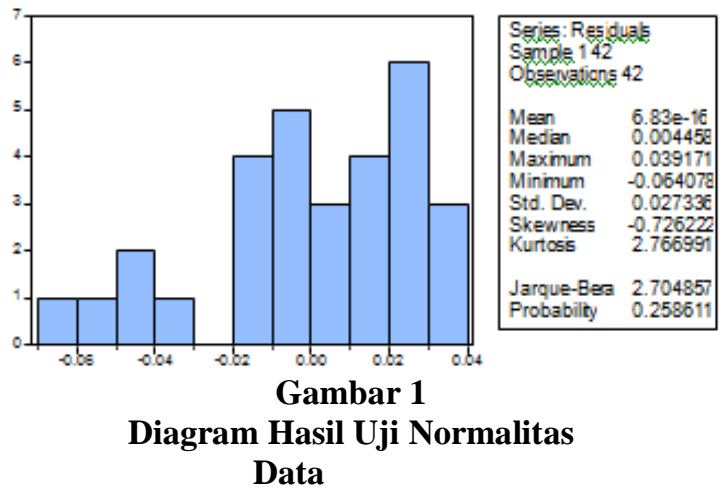

\section{Pengujian Masalah Heteroskedastisitas}

Ada beberapa asumsi dalam suatu model regresi. Asumsi tersebut yaitu residual memiliki nilai rata-rata nol, residual memiliki varians yang konstan dan residual suatu observasi tidak saling berhubungan dengan residual observasi lainnya, sehingga dihasilkan estimator yang BLUE. Jika asumsi ini tidak terpenuhi, maka akan menimbulkan permasalahan pada prediksi model yang dibangun. Oleh sebab itu diperlukan pengujian terhadap model untuk 
mengetahui keberadaan masalah heteroskedastisitas.

Pada penelitian ini. pengujian masalah heteroskedastisitas menggunakan uji White. Uji White dilakukan dengan mengukur nilai probabilitas dari $\mathrm{n}^{*} \mathrm{R}^{2}$ (observation* $R$-Square). Jika nilai probabilitas $\mathrm{n} * \mathrm{R}^{2}$ lebih besar daripada 0.05 $(\alpha=5 \%)$ maka mengindikasikan bahwa pada model tersebut tidak terdapat masalah heteroskedastisitas, dan sebaliknya jika nilai probabilitas $n * \mathrm{R}^{2}$ lebih kecil daripada 0.05 $(\alpha=5 \%)$ maka mengindikasikan bahwa pada model tersebut terdapat masalah heteroskedastisitas. Hasil pengujian heteroskedastisitas dengan menggunakan uji White sebagai berikut.

\section{Tabel 5}

\section{Heteroskedasticity Test: White Sumber : Data diolah 2016}

\begin{tabular}{llll}
\hline \hline F-statistic & 0.897638 & Prob.F(6,23) & 0.5133 \\
Obs ${ }^{*}$-squared & 5.692095 & Prob.Chi-Square(6) & 0.4585 \\
Scaled explained SS & 3.777294 & Prob. Chi-Square(6) & 0.7068
\end{tabular}

Dari tabel hasil pengujian heteroskedastisitas, diperoleh nilai probabilitas dari Obs*R-squared adalah sebesar 0.4585 , nilai ini lebih besar daripada $0.05(\alpha=5 \%)$ atau $0.4585>0.05$ yang mengindikasikan bahwa pada model tersebut tidak terdapat masalah heteroskedastisitas

\section{Pengujian Masalah Autokorelasi}

Autokorelasi menunjukkan korelasi di antara anggota serangkaian observasi yang diurutkan menurut waktu dan ruang. Untuk melakukan pengujian dilakukan pengujian LM (metode Bruesch Godfrey). Metode ini didasarkan pada nilai $\mathrm{F}$ dan Obs*R-squared, di mana jika nilai probabilitas dari Obs*Rsquared melebihi tingkat kepercayaan, maka $\mathrm{H}_{0}$ diterima yang menunjukkan bahwa pada model tidak terdapat masalah autokorelasi. Hasil pengujian autokorelasi dengan LM (metode Bruesch Godfrey) sebagai berikut.

\author{
Tabel 6 \\ Bruesch Godfrey Serial Correlation LM \\ Test
}

Sumber : Data diolah 2016

\begin{tabular}{|c|c|c|c|}
\hline F-statistic & 2.955214 & Prob. F(2,24) & 0.0712 \\
\hline $\mathrm{Obs}_{5}{ }^{\mathrm{R}}$-squared & 5.928127 & Prob. Chi-Square(2) & 0.0516 \\
\hline
\end{tabular}

autokorelasi, diperoleh nilai probabilitas dari Obs*R-squared adalah sebesar 0.0516, nilai ini lebih besar daripada $0.05(\alpha=5 \%)$ atau $0.0516>0.05$ yang mengindikasikan bahwa pada model tersebut tidak terdapat masalah autokorelasi.

\section{Pengujian Masalah Multikolinieritas}

Secara umum masalah mutikolinieritas yaitu terdapatnya korelasi antara variabel-variabel independen dalam sebuah model. Jika dalam suatu model terdapat masalah multikolinieritas, maka akan terlihat Nilai $\mathrm{R}^{2}$ yang tinggi. namun banyak variabel independen yang tidak signifikan atau tidak ada satu variabel independen pun yang signifikan.

Dalam penelitian ini. pengujian masalah multikolinieritas diuji dengan menggunakan metode Pairwaise Correlation Matrix dengan hasil sebagai berikut.

\section{Tabel 7}

Tabel Pairwise Correlation Matrix Sumber : Data diolah 2016

\begin{tabular}{|l|r|r|r|}
\hline VARIABEL & DPK & KYD & NPL \\
\hline DPK & 1 & -0.036309 & -0.127022 \\
\hline KYD & -0.036309 & 1 & -0.433921 \\
\hline NPL & -0.127022 & -0.433921 & 1 \\
\hline
\end{tabular}

Pada tabel 7 terlihat bahwa tidak terdapat koefisien yang lebih besar daripada 0.8. Sehingga dapat disimpulkan bahwa pada model tidak terdapat masalah multikolinieritas. 


\section{Regresi Linear Berganda}

Setelah dilakukan uji asumsi klasik, maka dilanjutkan dengan perhitungan regresi linear berganda. Model persamaan yang digunakan sebagai berikut.

$L a b a_{t}=\beta_{0}+\beta_{1} D P K_{t}+\beta_{2} K Y D_{t}+\beta_{3} N P L_{t}+$ $u_{\mathrm{t}}$

Setelah dilakukan perhitungan regresi linear berganda, diperoleh hasil perhitungan sebagai berikut.

Tabel 8

\section{Hasil Perhitungan Regresi Linear Berganda}

Sumber : Data diolah 2016

\begin{tabular}{|l|r|r|r|}
\hline Variable & Coefficient & t-Statistic & \multicolumn{1}{c|}{ Prob } \\
\hline C & 2.430378 & 0.325659 & 0.7473 \\
\hline DPK & 1.19031 & 2.907493 & 0.0074 \\
\hline KYD & -0.966186 & -0.441839 & 0.6623 \\
\hline NPL & -0.003956 & -0.525393 & 0.6038 \\
\hline R-squared & \multicolumn{3}{|l|}{$\mathbf{0 . 2 6 9 0 4 4}$} \\
\hline F-statistic & 3.18995 \\
\hline Prob(F-statistic) & $\mathbf{0 . 0 4 0 2 2 7}$ \\
\hline
\end{tabular}

Tabel 8 diatas, jika dilihat secara sekilas maka besaran probabilitas masing-masing variabel independen, terlihat bahwa terdapat satu variabel independen yang berpengaruh terhadap kredit yang disalurkan. Namun, diperlukan pengujian lebih lanjut untuk memastikan hal tersebut.

\section{Pengujian Statistik}

Uji t-statistik

Uji $\mathrm{t}$ dilakukan dengan membandingkan antara t-statistik (nilai $\mathrm{t}$ yang dihasilkan dari proses regresi) dan nilai $\mathrm{t}$ yang diperoleh dari tabel. Hipotesis yang digunakan dalam uji t yaitu:

$\mathrm{H}_{0} \quad$ : Tidak terdapat pengaruh antara variabel independen secara individu terhadap variabel dependen
$\mathrm{H}_{1} \quad$ : Terdapat pengaruh antara variabel independen secara individu terhadap variabel dependen

Pengujian dilakukan dengan pengujian dua arah pada tingkat signifikansi $5 \%$, dengan kriteria. bila t-statistik $\geq \mathrm{t}$-tabel, maka disimpulkan bahwa variabel independen tersebut berpengaruh terhadap variabel dependen. Sebaliknya. jika tstatistik < dari t-tabel, maka variabel independen tidak berpengaruh terhadap variabel dependen.

Tabel 9

Nilai Batas Kritis Uji t

Sumber : Gujarati

\begin{tabular}{|l|l|}
\hline \multirow{2}{*}{ Df } & $\mathbf{\alpha}$ \\
\cline { 2 - 2 } & $\mathbf{0 . 0 5}$ \\
\hline 42 & \pm 2.056 \\
\hline *df = n-k-1 $(42-3-1=38)$ \\
\hline $\mathrm{n}=$ Jumlah observasi $(42)$ \\
\hline $\mathrm{k}=$ Jumah parameter $(3)$ \\
\hline
\end{tabular}

Tabel 10

Hasil Pengujian t-statistik

Sumber : Data diolah

\begin{tabular}{|l|r|r|l|}
\hline Variabel & t-statistik & \multicolumn{1}{c|}{ Prob. } & \multicolumn{1}{|c|}{$\mathrm{H}_{0}$} \\
\hline DPK & 2.907493 & $0.0074^{\text {*** }}$ & Ditolak \\
\hline KYD & -0.441839 & 0.6623 & Diterima \\
\hline NPL & -0.525393 & 0.6038 & Diterima \\
\hline
\end{tabular}

Keterangan :

$$
\begin{array}{ll}
* & : \text { Signifikan pada } 10 \% \\
* * & : \text { Signifikan pada } 5 \% \\
* * * & : \text { Signifikan pada } 1 \%
\end{array}
$$

Uji t terdapat pada tabel 9 dan tabel 10. Penjelasan hasil uji $t$ terhadap persamaan variabel-variabel yang mempengaruhi kredit yang disalurkan sebagai berikut :

\section{- Variabel DPK}

Nilai $t_{\text {hitung }}$ variabel DPK sebesar 2.907493 lebih besar daripada $t_{\text {tabel }}$ pada tingkat signifikansi $5 \%$ sebesar 2.056 dengan $p$ - 
value sebesar 0.0074 dan arah pengaruhnya positif, sehingga $\mathrm{H}_{0}$ ditolak dan diperoleh kesimpulan bahwa secara parsial variabel DPK berpengaruh signifikan terhadap kredit yang disalurkan dengan arah pengaruh yang positif.

\section{- Variabel KYD}

Nilai - $t_{\text {hitung }}$ variabel KYD sebesar 0.441839 lebih besar daripada $-\mathrm{t}_{\text {tabel }}$ pada tingkat signifikansi 5\% sebesar -2.056 dengan $p$-value sebesar 0.6623 dan arah pengaruhnya negatif, sehingga $\mathrm{H}_{0}$ diterima dan diperoleh kesimpulan bahwa secara parsial variabel KYD tidak berpengaruh signifikan terhadap kredit yang disalurkan dengan arah pengaruh yang negatif.

\section{- Variabel NPL}

Nilai -t $t_{\text {hitung }}$ variabel NPL sebesar -0.525393 lebih besar daripada - $t_{\text {tabel }}$ pada tingkat signifikansi $5 \%$ sebesar -2.056 dengan $p$ value sebesar 0.6038 dan arah pengaruhnya negatif, sehingga $\mathrm{H}_{0}$ diterima dan diperoleh kesimpulan bahwa secara parsial variabel NPL tidak berpengaruh signifikan terhadap kredit yang disalurkan dengan arah pengaruh yang negatif.

\section{Uji F-statistik}

Uji F-statistik dilakukan untuk mengetahui pengaruh variabel independen secara keseluruhan terhadap variabel dependen. Dalam uji F ini akan dibandingkan antara nilai F-hitung dari persamaan

dan nilai F-tabel. Hasil pengujian akan menunjukkan kesimpulan sebagai berikut.

- $\mathrm{H}_{0}$ diterima jika F-statistik < F-tabel. hal ini berarti variabel independen secara simultan tidak mempengaruhi variabel dependen secara signifikan

- $\mathrm{H}_{0}$ ditolak jika F-statistik $\geq$ F-tabel. hal ini berarti variabel independen secara simultan mempengaruhi variabel dependen secara signifikan.

\author{
Tabel 11
}

Nilai Batas Kritis Uji F

Sumber : Gujarati

\begin{tabular}{|l|l|}
\hline \multirow{2}{*}{ Df } & $\boldsymbol{\alpha}$ \\
\cline { 2 - 2 } & 0.05 \\
\hline 42 & \pm 2.975 \\
\hline${ }^{*} \mathrm{df}=\mathrm{n}-\mathrm{k}-1$ & $(42-3-1=38)$ \\
\hline $\mathrm{n}=$ Jumlah observasi $(42)$ \\
\hline $\mathrm{k}=$ Jumah parameter $(3)$ \\
\hline
\end{tabular}

Hasil pengujian menunjukkan bahwa nilai $F_{\text {hitung }}$ (tabel 4.8) sebesar 3.189950 lebih besar dari nilai $F_{\text {tabel }}$ (2.975) pada tingkat signifikansi $5 \%$. Sehingga $\mathrm{H}_{0}$ ditolak, yang menunjukkan bahwa variabel DPK, KYD dan NPL secara bersama-sama berpengaruh signifikan terhadap variabel kredit yang disalurkan.

\section{Uji Koefisien Determinasi $\left(\mathbf{R}^{2}\right)$}

Tujuan dari pengujian ini yaitu untuk mengetahui besarnya kemampuan variabel independen untuk menjelaskan variabel dependen secara bersamaan. Pengujian ini bermanfaat juga untuk mengukur kebaikan dan kebenaran hubungan antar variabel dalam model yang digunakan. Nilai $R^{2}$ berkisar antara nol dan satu. Semakin mendekati satu. maka semakin dekat hubungan antara variabel independen dan dependen. Sebaliknya, jika $\mathrm{R}^{2}$ semakin mendekati nol. maka semakin jauh hubungan antara variabel independen dan dependen.

Pada hasil estimasi. diperoleh besaran $\mathrm{R}^{2}$ sebesar 0.269044. Hal ini menunjukkan bahwa variabel independen menjelaskan variabel kredit yang disalurkan sebesar $26,90 \%$, sedangkan sisanya sebesar $73,10 \%$ dijelaskan faktor-faktor lain yang tidak termasuk dalam model.

Hasil penelitian Sigit Setiawan dan Winarsih (2011), menunjukkan bahwa DPK dan NPL berpengaruh terhadap laba. Pengaruh DPK terhadap laba adalah positif artinya dana masyarakat yang dihimpun dan disalurkan kembali ke masyarakat cukup optimal dan mengakibatkan laba yang diperoleh bank sudah optimal sehingga laba 
menjadi positif. Sedangkan pengaruh kredit non lancar terhadap laba adalah negatif artinya apabila jumlah kredit non lancar tinggi akan mengakibatkan laba yang diperoleh bank menurun atau kurang optimal, sehingga laba yang kurang optimal mengakibatkan laba kurang optimal pula. Sedangkan hasil penelitian Ahmad Sigit (2013) menunjukkan bahwa jumlah kredit yang disalurkan dan tingkat NPL berpengaruh terhadap perubahan laba baik secara parsial maupun simultan.

\section{Simpulan dan Saran}

\section{Simpulan}

Dari hasil perhitungan dan analisis yang dilakukan pada bab sebelumnya, maka dapat disimpulkan :

1. Dana Pihak Ketiga (DPK) berpengaruh signifikan terhadap laba pada Bank Nusantara Parahyangan Cabang Sudirman;

2. Besarnya Kredit Yang Disalurkan tidak berpengaruh signifikan terhadap laba pada Bank Nusantara Parahyangan Cabang Sudirman;

3. Besarnya Kredit Non Lancar tidak berpengaruh signifikan terhadap laba pada Bank Nusantara Parahyangan Cabang Sudirman;

4. Penelitian menunjukan variabel Jumlah Dana Pihak Ketiga, Kredit Yang Disalurkan dan Kredit Non Lancar secara simultan mempunyai pengaruh yang signifikan terhadap laba pada Bank Nusantara Parahyangan Cabang Sudirman.

\section{Saran}

1. Pihak Bank

a. Pihak manajemen bank harus lebih memperhatikan perkembangan dana pihak ketiga guna mengantisipasi cost of fund yang ditimbulkan untuk menjaga keseimbangan keuangan pada bank. b. Pihak manajemen bank disarankan untuk lebih banyak menyalurkan kredit kepada masyarakat agar laba yang didapat menjadi lebih besar

c. Pihak bank sudah cukup bagus dalam mengelola rasio NPL tetapi harus berusaha maksimal agar nilai NPL berada di bawah $1 \%$.

2. Bagi peneliti selanjutnya : Diharapkan dapat meneliti dengan variabel lain diluar variabel ini agar memperoleh hasil yang lebih bervariatif yang dapat menggambarkan hal-hal apa saja yang berpengaruh terhadap jumlah laba.

\section{Daftar Pustaka}

Arianti, Wuri dan Muharamm, Harjum, "analisis pengaruh Dana Pihak Ketiga (DPK), Capital Adequacy Ratio (CAR), Non Performing Financing (NPF), dan Return Of Asset (ROA) terhadap Pembiayaan Pada Perbankan Syariah", 2011

Arikunto, Suharsimi (2002) Prosedur Penelitian Suatu Pendekatan Praktek Yogyakarta; Rineka Cipta

Arthesa, A dan Handiman, E. (2006) Bank dan Lembaga Keuangan Bukan Bank Jakarta: PT.Indeks

Ayupri, (2010), Pengaruh Non Performing Loan Terhadap Profitabilitas pada PT bank Eksekutif Internasional Tbk Bandung : program Studi Manajemen Universitas Pendidikan Indonesia

Bank Indonesia (1998), Surat Edaran Bank Indonesia No 3/30/DPNP 2001. Jakarta: Bank Indonesia

Bank Indonesia. (2004), Surat Edaran Bank Indonesia No 6/238DPNP 2004. Jakarta: Bank Indonesia

Bank Indonesia. (2012), Surat Edaran Bank Indonesia No 14/26/2012/DKBU. Jakarta: Bank Indonesia

Bank Nusantara Parahyangan, Laporan Keuangan 2014 dan 2015 https://www.google.co.id/url?sa=t $\& \mathrm{rct}=\mathrm{j} \& \mathrm{q}=\&$ esrc $=\mathrm{s} \&$ source $=$ web $\&$ 
$\mathrm{cd}=2 \& \mathrm{cad}=\mathrm{rja} \& u a c t=8 \& \mathrm{ved}=0 \mathrm{ahU}$ KEwiz0uW38o_OAhWMP48KHV s4DFMQFggiMAE\&url=http\%3A $\% 2 \mathrm{~F} \% 2 \mathrm{Fw} w w$. bankbnp.com\%2Fin vestor-relation $\% 2$ Ffinnancialreport\%2Ffinnancial-reporttriwulan\&usg $=$ AFQjCNHdaNM $2 \mathrm{z}$ oMf0uW7c_mk8RplGcztzw\&sig2 $=$ kwdLMPwntglqiooawcSIQ\&bvm=bv. 127984354 ,d. c2I

Dendawijaya, Lukman (2009) Manajemen Perbankan, Jakarta : Ghalia, Indonesia

Efferen, Sujoko (2008) Metode Penelitian Akuntansi, Yogyakarta:Graha Ilmu

Firdaus, Rachmat (2009) Manajemen Perkreditan bank Umum, Teori Masalah Kebijakan dan Aplikasinya Lengkap dengan Analisis Kredit, bandung : Alfabeta

Gujarati, Damodar N \& Porter, Dawn C. 2012. Dasar-dasar Ekonometrika. Penerbit Salemba Empat. Jakarta.

Grier, W.A (2007) Credit Analysis of Financial Instituions Second Edition London : Euromoney Institutional Investor Ple

Hasibuan (2007), Lembaga Keuangan, PT Rajagragindo Persada, Jakarta

Ibrahim, Johannes (2004) Cross Default \& Cross Collateral Sebagai Upaya Penyelesaian Kredit Bermasalah, Bandung : Refika Aditama
Iskandar, Syamsu (2013) Bank dan lembaga Keuangan Lainnya, Jakarta : Inmedia

Kasmir.2011. Manajemen Perbankan. Jakarta: PT Raja Grafindo Persada

Kasmir (2012). Bank dan Lembaga Keuangan Lainnya, Jakarta : Rajagrafindo Persada

McClave, dkk. 2010. Statistik untuk Bisnis dan Ekonomi. Erlangga. Jakarta

Widarjono, 2005. Ekonometrika : Teori Dan Aplikasi. Penerbit Ekonisia Fakultas Ekonomi UII. Yogyakarta.

Setiawan, Sigit \& Winarsih. 2011. Faktorfaktor Yang Mempengaruhi Pertumbuhan Laba Bank Syariah Di Indonesia. Jurnal Ekonomi Manajemen-Akuntasi vol. 18 No. 31. Siamat, Dahlan. 1993. Manajemen Bank Umum. Jakarta: Intermedia

McClave, dkk. 2010. Statistik untuk Bisnis dan Ekonomi. Erlangga. Jakarta

Gujarati, Damodar N \& Porter, Dawn C. 2012. Dasar-dasar Ekonometrika. Penerbit Salemba Empat. Jakarta.

Widarjono, 2005. Ekonometrika : Teori Dan Aplikasi. Penerbit Ekonisia Fakultas Ekonomi UII. Yogyakarta.

http://ejournal.undiksha.ac.id/index.php/JJM /article/viewFile/4136/3256

http://ejurnal.stiedharmaputrasmg.ac.id/index.php/JEMA/article/ download/84/10 